\title{
The influence of light color on the rooting of 'Horim Golden' Chrysanthemum cuttings
}

\author{
EDWARD BOROWSKI and LIDIA KOZLOWSKA
}

\begin{abstract}
Institute of Natural Principles of Plant Production, Agricultural Academy, Akademicka 15, 20-934 Lublin, Poland
\end{abstract}

(Received: May 14, 1984)

\begin{abstract}
The influence of three different colors of light; blue, green and red, compared with white light as the control, on the rooting of Chrysanthemum cuttings, is presented in this paper. The mother plants and cuttings were irradiated during rooting with different colors of light. This was shown to have had visible influence on the morphological differentiation of cuttings. It also affected the carbohydrate content in them. The rooting of the cuttings reflected this influence. The cuttings obtained from plants grown under white (control) or red light were characterized by well-developed root systems in terms of the number, length and mass of the roots. The cuttings from the plants grown under green light were the worst. The influence of the color of the light on the speed with which the first roots were formed was the reverse. The cuttings from the plants irradiated with green light rooted the quickest, next in order were those from plants irradiated with blue, red and white light. Irradiating cuttings with differently colored light during rooting only had an effect on the number of roots formed. This number was high, close to that of control cuttings, in cuttings exposed to red light, decidedly lower in those exposed to blue and, in particular, green light.
\end{abstract}

\section{INTRODUCTION}

During propagation of decorative plants in winter, additional irradiation is presently employed. This clearly increases both the number and rooting capability of the cuttings obtained in this way (Jerzy, 1976; Nilsen, 1976; Moe, 1977). The studies done until now on the influence of light on the rooting of plants dealt mainly with the intensity of the light (Moe, 1977; Fischer and Hansen, 1977; Borowski et al., 1981). No special attention was given to the quality of the light in respect to its color. In the few studies on this subject, the opinion is divided. Fletcher (1965) and Ruge (1953) found that red light stimulated the rooting of plants, whereas Shapiro (1958) (ref. Fernquist, 1966) reported that red light inhibited rooting. 
In light of the above, it seemed purposeful to undertake studies on the effect of using different colored light during the growth of mother plants on the rooting of cuttings obtained from them, and to determine as well the effect of direct irradiation of cuttings on their rooting.

\section{MATERIAL AND METHODS}

The study was done on Chrysanthemums of the 'Horim Golden' variety. The experiments were carried out in the vegetation rooms of the Agricultural Academy in Lublin during two periods: from Nov. 16, 1981 to Jan. 3, 1982 and from Dec. 12, 1982 to Feb. 6, 1983. The plants were illuminated during the experiments with $40 \mathrm{~W}$ fluorescent lamps which emitted white, red, blue and green light. The white light was taken as the control. The intensity of the light was $5000 \mathrm{~lx}$, time of irradiation $14 \mathrm{~h}$. The characteristics of the lamps used are presented on Figure 1. The curves of the relative spectrum of the light obtained indicate that it was not monochromatic, but only light with a decided predominance of a particular wave-length, which, in effect, gave a given color.

The study presented here encompasses two experiments, each of which was made up of two separate parts. In the first part of the experiment, mother plants were irradiated with different colored light and the cuttings obtained from them were rooted under white light. In the second part of the experiment, the mother plants were given white light during growth and the cuttings from them were rooted under different colored light. Each experiment was run in duplicate. In the experiment where mother plants were irradiated with light of different colors, 10 plants were illuminated with each color. From these 10 plants, 50 cuttings were made and rooted under white light. In the experiment where the cuttings were illuminated directly, 40 plants were irradiated with white light, 200 cuttings were taken from them and 50 cuttings were rooted under each color of light.

The mother plants were grown in plastic containers with a latice bottom, filled with a mixture of peat and garden earth at a ratio of $1: 1$. Every few days the plants were watered with tap water and periodically fertilized with a fertilizer mixture, MIS-1. The air temperature during the growth period of the mother plants was from $23-25^{\circ} \mathrm{C}$, humidity $-60 \%$ f.w.c. After the mother plants formed well-developed shoots, that is, after about 6 weeks, cuttings were prepared. They were $5-7 \mathrm{~cm}$ long and had 3-4 well-developed leaves.

The cuttings were placed in openings made in styrofoam sheets, $1 \mathrm{~cm}$ thick, suspended on the surface of the water in plastic containers, $65 \times 55 \mathrm{~cm}$. The containers were filled with distilled water to a depth of $7 \mathrm{~cm}$. The cuttings were rooted for 21 days. The water and air temperatures were kept between $23-25^{\circ} \mathrm{C}$. The water was aerated during the entire rooting period. The air humidity in the vicinity of the cuttings was kept between $80-90 \%$ f.w.c.

The rooting of cuttings in hydroponic cultures enabled the rate of root formation to be followed during the course of the experiment. To this end, beginning from 

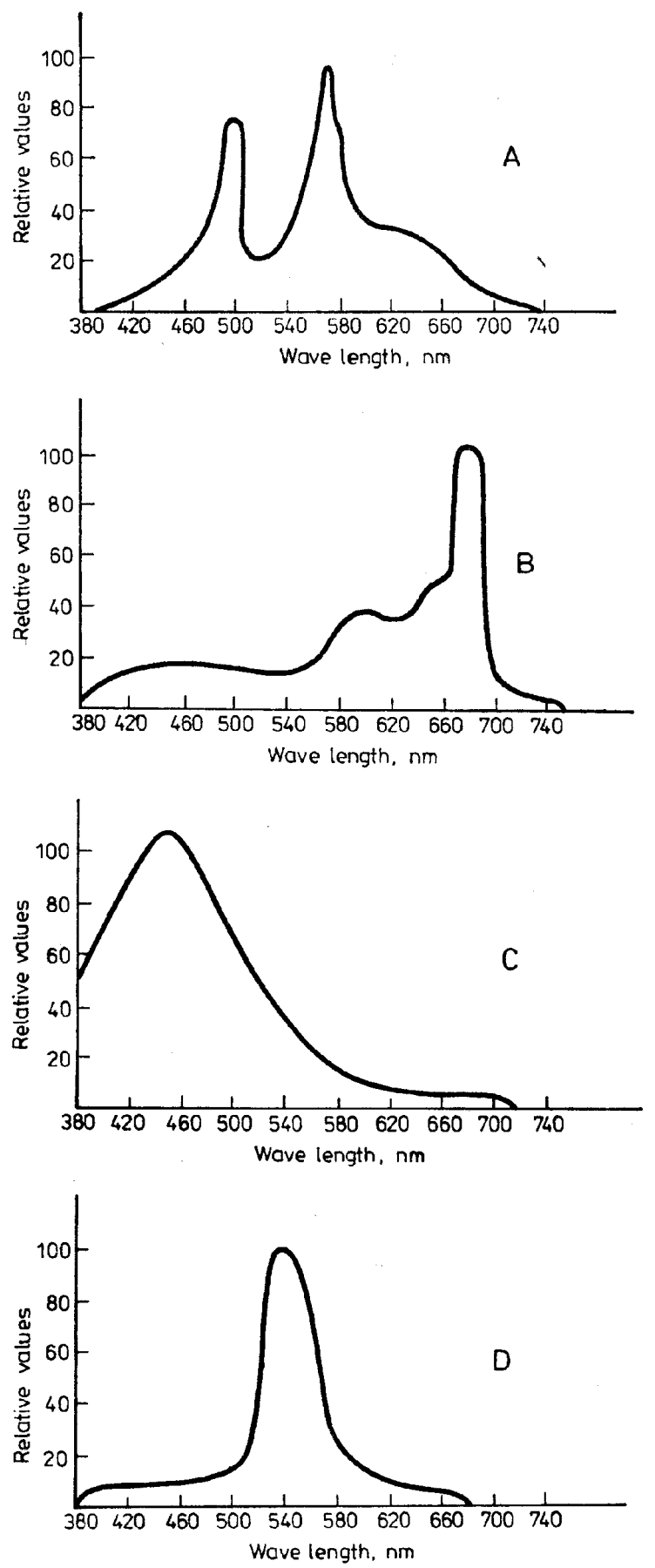

Fig. 1. Curves of the relative spectrums of fluorescent lamps emitting light of the following colors: A - white, B - red, C - blue, D - green 
the first day of rooting, the number of cuttings which had formed at least one root, $1 \mathrm{~mm}$ in length, was determined each day. The number of cuttings beginning to root on successive days during the experiment is presented as a percentage in relation to the total number of cuttings in the series.

The experiment was terminated after 21 days because no more new roots were being initiated on the cuttings. At this time, the number of roots per cutting, length of the longest root, fresh and dry mass of the roots were determined. The numerical data thus obtained was subjected to statistical analysis using the complete randomization system and Tukey's ranges of confidence. In the experiments on irradiation of mother plants, where distinct morphological differences between the cuttings from them were found, the height, base diameter and fiesh and dry mass before and after rooting were determined. The percentage of sugars (assayed colorimetrically by the phenol method) was determined in the shoots of the mother plants from which cuttings were obtained.

Due to the fact that the effect of light on rooting was similar in both experiments, all of the numerical data presented in the tables and figures are the averages from both experiments.

\section{RESULTS}

\section{Experiments on irradiation of mother Chrysanthemum plants}

Biometrical characteristics and sugar content of cuttings. The results presented in Table 1 indicate that the color of the fluorescent light used on mother Chrysanthemum plants had a significant influence on the growth and development of stems, hence, on some of the morphological traits of the cuttings as well as on their sugar content. The most favorable growth and development of shoots was obtained using red light (Fig. 2). Cuttings taken from shoots which had grown in this light were characterized by the highest fresh and dry mass, as well as the largest diameter and height. Most closely resembling them were cuttings from plants which had been irradiated with white light. Cuttings from plants irradiated with blue and, in particular, green light, clearly differed in respect to mass and height (Fig. 2). Cuttings from mother plants cultivated under green light were characterized by an average 3-fold lower mass compared with cuttings from plants growing in red light (Table 1). The differences in the percentage of sugars in the cuttings were not high, nonetheless, cuttings illuminated with white light contained relatively the most of these substances, those illuminated with blue light - the least. The accumulation of sugars in the dry mass of the cuttings was dependent on the size of the cuttings. For this reason the cuttings obtained from plants grown under white or red light were an average 3 times richer in carbohydrates than cuttings from plants illuminated with blue, and especially, green light (Table 1).

Differences in the growth and mass of the cuttings connected with the different irradiation of their mother plants did not diminish during their rooting under uniform 
Table 1

The influence of irradiating Chrysanthemum mother plants with different colors of light on the height of cuttings, diameter of the base, fresh and dry weight before and after rooting as well as on the carbohydrate content in the dry weight on the cuttings

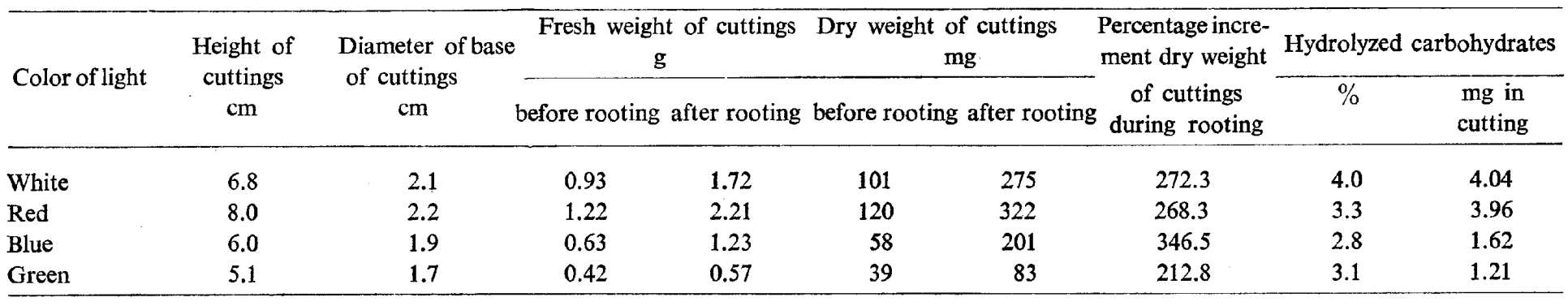




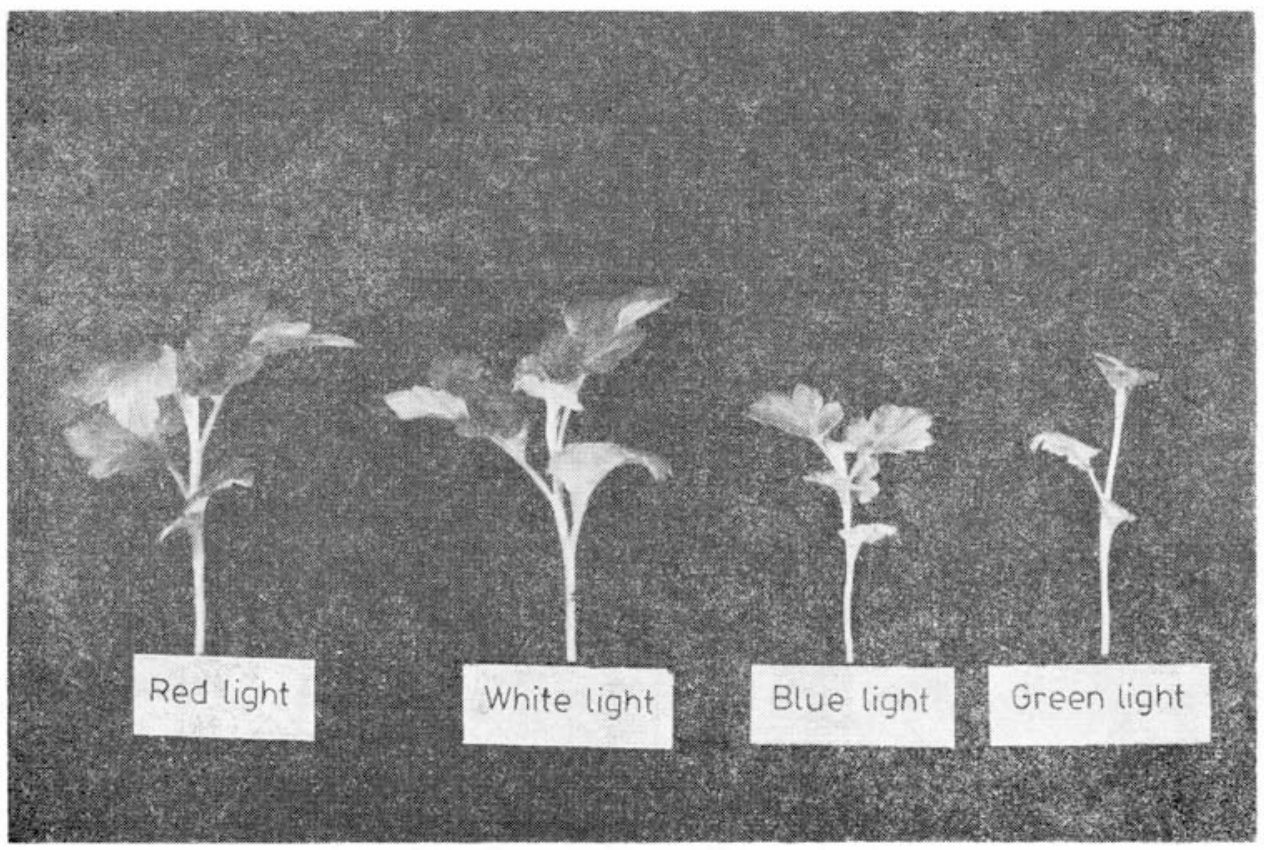

Fig. 2. Chrysanthemum cuttings obtained from mother plants irradiated with light of different colors before rooting

illumination with white light. Varied increases in the percentage of dry weight were noted during rooting. Cuttings from plants irradiated with blue light were characterized by the highest increases, a decidedly smaller increase was typical for cuttings grown under white and red light, whereas the lowest increase was in cuttings grown under green light.

Rooting of cuttings. The clear morphological differences among the cuttings resulting from irradiation of the mother plants with differently colored light, had significant influence on the rooting of the cuttings.

Cuttings from mother plants illuminated with green light were characterized by the fastest rooting time. These cuttings already formed roots on the fourth day of the experiment, whereas cuttings from plants irradiated with blue or red light began this process 2 days later and those from white light -3 days later. After 8 days of rooting, all of the cuttings grown in green light had begun to form roots, whereas the percentage of rooted cuttings grown under blue, red or white light was $46 \%$, $34 \%$ and $9 \%$, respectively (Fig. 3). The initiation of root formation by cuttings, from plants grown under blue light falls on the 11th day, those from red or white light, on the 12th day of rooting.

The irradiation of mother Chrysanthemum plants with differently colored light also had a significant effect on the rooting of cuttings expressed by the number and length of the formed roots. Cuttings from plants irradiated with white light rooted 
the best. Significantly fewer roots were formed by cuttings obtained from plants grown in red or blue light. The most poorly rooted cuttings were obtained from plants grown under green light (Table 2). There, cuttings formed nearly twice as few roots as control cuttings in addition to which, the roots were much shorter.

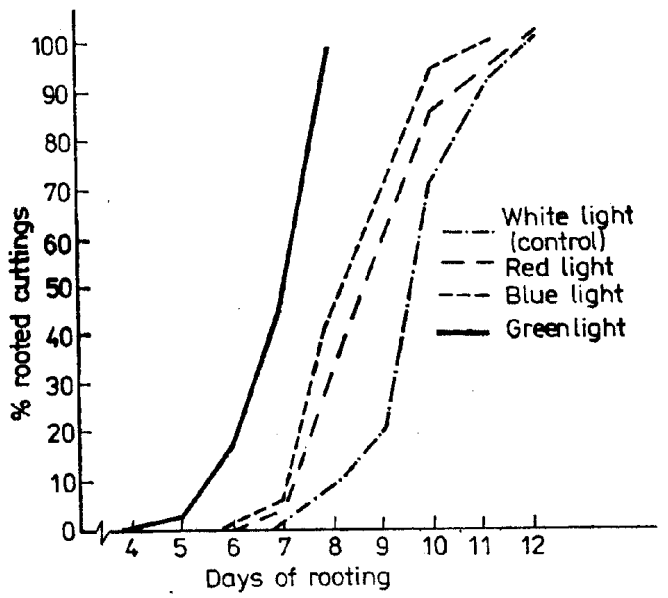

Fig. 3. Dynamics of rooting of Chrysanthemum cuttings obtained from mother plants irradiated with different colors of light

Table 2

The influence of irradiating Chrysanthemum mother plants with light of different colors on the number of roots, length of the longest root as well as fresh and dry weight of roots on a cutting

\begin{tabular}{lcccc}
\hline Color of light & $\begin{array}{c}\text { Number of roots } \\
\text { per cutting }\end{array}$ & $\begin{array}{c}\text { Length of the longest } \\
\text { root per cutting } \\
\mathrm{cm}\end{array}$ & $\begin{array}{c}\text { Fresh weight } \\
\text { of roots } \\
\text { mg }\end{array}$ & $\begin{array}{c}\text { Dry weight of } \\
\text { roots } \\
\text { mg }\end{array}$ \\
\hline White & 43.4 & 8.3 & 237.2 & 17.9 \\
Red & 38.2 & 8.7 & 254.8 & 18.4 \\
Blue & 37.1 & 4.3 & 82.2 & 7.9 \\
Green & 23.6 & 3.5 & 33.3 & 2.5 \\
\hline LSD at $0.95 \%$ & 5.0 & 1.1 & 20.7 & 2.2 \\
\hline
\end{tabular}

The average fresh and dry mass of the formed root system remained directly correlated with the number and length of the roots. Cuttings from plants grown in green light were characterized by the lowest mass of the roots. Cuttings obtained from plants grown under red and white light formed roots of approximately 7-fold greater mass, those grown in blue light - of about 3 times greater mass.

\section{Experiments on direct irradiation of Chrysanthemum cuttings}

The Chrysanthemum cuttings irradiated during rooting with fluorescent light of different colors were characterized by decidedly less differentiated rooting dynamics than the cuttings obtained from mother plants grown under different colors 
of light. Irregardless of the color of the light used, only a small number of the cuttings had begun to form roots on the 7th day of rooting. Full initiation of rooting was obtained by the cuttings in all of the combinations on the 12th day of the experiment. Somewhat greater differences in the rate of rooting were seen between the 7 th and 9 th days. The cuttings receiving white light exhibited the highest root formation rate $(20 \%)$, those receiving red light formed roots much more slowly $(10 \%)$ and those given green or blue light were the slowest $(6 \%$ and $4 \%$, respectively). These differences diminished in the later stages of rooting (Fig. 4).

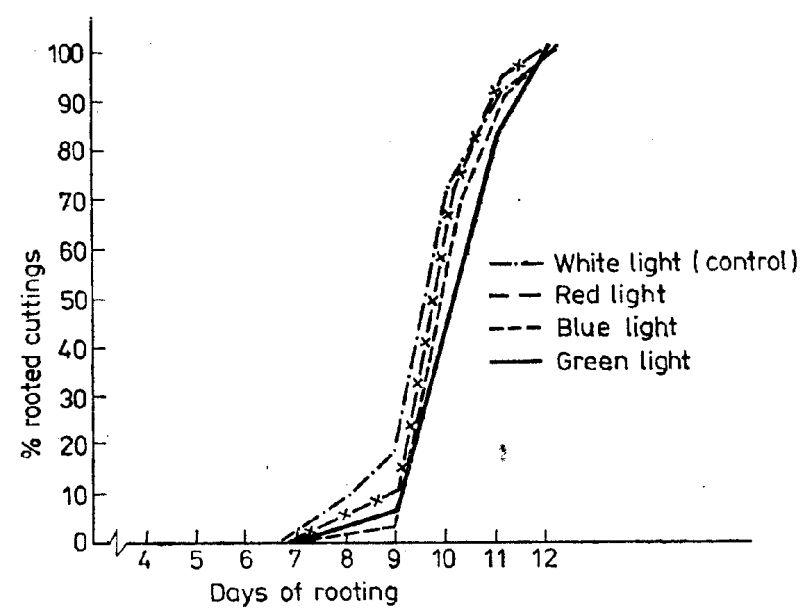

Fig. 4. Dynamics of rooting of Chrysanthemum cuttings irradiated with different colors of light

The color of the light influenced the number of formed roots much more than it did the speed with which the cuttings rooted. Cuttings given white (control) or red light formed a large number of roots. A significantly smaller number was characteristic for cuttings receiving blue as well as green light (Table 3). Differen-

Table 3

The influence of irradiating Chrysanthemum cuttings with light of different colors on the number of roots, length of the longest root as well as on the fresh and dry weight of roots on a cutting

\begin{tabular}{lcccc}
\hline Color of light & $\begin{array}{c}\text { Number of roots } \\
\text { per cutting }\end{array}$ & $\begin{array}{c}\text { Length of the longest } \\
\text { root per cutting } \\
\mathrm{cm}\end{array}$ & $\begin{array}{c}\text { Fresh weight of } \\
\text { roots } \\
\mathrm{mg}\end{array}$ & $\begin{array}{c}\text { Dry weight of } \\
\text { roots } \\
\mathrm{mg}\end{array}$ \\
\hline White & 43.4 & 8.3 & 237.2 & 17.9 \\
Red & 44.8 & 8.6 & 282.6 & 19.4 \\
Blue & 37.0 & 7.6 & 203.6 & 11.6 \\
Green & 27.8 & 7.9 & 169.7 & 9.4 \\
\hline LSD at $0.95 \%$ & 6.79 & no significant dif- & 70.1 & 30.6 \\
& & ferences & \\
\hline
\end{tabular}


ces in the color of light received by cuttings during rooting did not have an effect on the length of the roots.

The average dry mass of the root system of the cuttings was dependent on the number of roots formed and not on the mass of individual roots. It was therefore twice as high in cuttings receiving red or white light than in those given blue and especially, green light (Table 3).

\section{DISCUSSION}

The results of the studies presented here indicate that the use of different colored light during growth of mother plants had a greater effect on rooting of cuttings than did its use during the rooting of cuttings. This is undoubtedly connected with the fact that in the case of irradiation of mother plants, the process of growth and development of shoots, from the moment of their initiation to the moment they were cut, took place under different lighting conditions. The result of this was the obtaining of cuttings of different mass, height and base diameters, as well as sugar content. Hence, cuttings which were in clearly different "physiological states" entered into the process of rooting. In the case of direct irradiation of cuttings, rooting was begun by cuttings which did not differ from each other in respect to their "physiological state", in which differences only began to arise during rooting. Taking into account the fact that on the cuttings, the first roots already appeared on the 6th day of rooting, and that the processes preceding the appearance of roots undoubtedly must have begun much earlier, it seems obvious that so short an illumination time did not excert a significant effect on the rate of root initiation as well as on their length. The significant effect of direct irradiation of cuttings on the number of roots formed should probably be linked with the influence of the colors of light used on the process of photomorphogenesis in plants. In the studied case, a large number of roots was formed by cuttings receiving red or white light, significantly less by those given blue and, especially, green. Similar results in respect to red and blue light were obtained by Fletcher (1965) on beans and Ruge (1953) on spiderwort.

In case of irradiance of mother plants with different colors of light, properly developed cuttings were obtained from plants given red or white light. Much inferior cuttings were obtained from plants given blue or green light. This fact undoubtedly results from the photosynthetic activity of the individual colors of light. This suggestion has been confirmed in the study by Inada Katsumi et al. (1980), done on several species of crop plants, in which it was found that only in red light was photosynthesis greater than in white, and in blue and especially green, the intensity of this process was lower. The certain results of the different intensities of photosynthesis due to different colors of light, were not only the different growth and shape of the cuttings, but also the unequal sugar contents. Although the differences in the percentages of sugars were small, the differences in the amounts of stored carbohydrates in whole cuttings were quite large. This fact may, to a certain extent, 
explain the different rooting of cuttings obtained from mother plants irradiated with different colored light. Cuttings obtained from plants given white or red light rooted the best and showed high accumulation of sugars in their mass. Those which rooted the worst, grew under green light and contained over three times less sugars. The relationship between the sugar content of cuttings and their ability to form roots found in this study is supported by the results of earlier works. Molnar and LaCroix (1972) determined that there is a correlation coefficient of 0.673 between the starch content and the number of roots in cuttings of Hydrangea macrophylla. However, no correlation was found for cuttings kept in the dark. Similar relationships are pointed to by the studies of other authors done on cuttings of Sinapis alba and Raphanus sativus (Lovell et al., 1972), Campanula isophylla (Haaland, 1976), Pisum sativum (Veierskov et al., 1976). Stoltz (1968), on the basis of studies done on Chrysanthemum cuttings, showed that the naturally easy-to-root variety, 'Bright Golden Anne', was characterized by a clearly higher starch content than the difficult-to-root variety, 'Mrs. Roy'. The color of the light had a completely different influence on the dynamics of the initiation of the first roots by the cuttings than it did on the number and length of the formed roots. The cuttings from dlants irradiated with green light began rooting much earlier than did the cuttings grown in red or white light. The regularity found in this experiment is difficult to explain due to the lack of similar studies.

\section{REFERENCES}

Borowski E., Hagen P., Moe R., 1981. Stock plant irradiation and rooting of Chrysanthemum cuttings in light or dark. Scientia Hortic. 15: 245-253.

Fischer P., Hansen J., 1977. Rooting of Chrysanthemum cuttings. Influence of irradiance during stock plant growth and of decapitation and disbudding of cuttings. Scientia Hortic. 7: 171-178.

Fletcher R. A., 1965. Effect of light quality on elongation adventitious root production and the relation of cell number and cell size to bean seedling elongation. Plant Physiol. 40: 541-548.

Haaland E., 1976. The effect of light and $\mathrm{CO}_{2}$ on the carbohydrates in stock plants and cuttings of Campanula isophylla Moretti. Scientia Hortic. 5: 353-361.

Inada Katsumi, Funakoshi Tatsuaki, Aoki Mikio, Fukui Masao, Katsura Naoki, 1980. Nikson sacumoku gakkai kidzi. Jap. J. Crop. Sci. 49: $34-41$.

Jerzy M., 1976. Ukorzenianie sadzonek złocieni ogrodowych (Chrysanthemum hortorum Bailey) w różnych warunkach sztucznego oświetlenia. Rocz. Akad. Rol. w Poznaniu 6: 67-79.

Lovell P. H., Jllsley A., Moore K. G., 1972. The effects of light intensity and sucrose on root formation, photosynthetic ability and senescence in detached cotyledons of Sinapis alba L. and Raphanus sativus L. Ann. Bot. 36: 123-134.

Moe R., 1977. Effect of light, temperature and $\mathrm{CO}_{2}$ on the growth of Campanula isophylla stock plants and on the subsequent growth and development of their cuttings. Scientia Hortic. 6: 129-141.

Molnar J. M., LaCroix L. J., 1972. Studies of the rooting of cuttings of Hydrangea macrophylla: enzyme changes. Can. J. Bot. 50: 315-322.

Nilsen J. H., 1976. Effects of irradiation of the mother plants on rooting of Pelargonium cuttings. Acta Hortic. 64: 65-69. 
Ruge U., 1953. Die Synthese der Bios - Wuchsstoffe in verschiedenen Spektralbereichen. Naturwiss. 7: 225-228.

Stoltz L. P., 1968. Factors influencing root initiation in an easy- and a difficult-to-root Chrysanthemum. Proc. Am. Soc. Hortic. Sci. 92: 622-626.

Veierskov B., Hansen J., Andersen A. S., 1976. Influence of cotyledon excision and sucrose on root formation in pea cuttings. Physiol. Plant. 36: 105-109.

\section{Wpływ barwy światła na ukorzenianie sadzonek złocienia ogrodowego odmiany 'Horim Golden'}

\section{Streszczenie}

W pracy omówiono wpływ trzech barw światła fluorescencyjnego, tj. światła czerwonego, niebieskiego i zielonego w odniesieniu do światła białego jako kontroli na ukorzenianie sadzonek złocienia ogrodowego odmiany 'Horim Golden'. Światłem o zróżnicowanej barwie traktowano rośliny mateczne lub sadzonki w trakcie ukorzeniania.

Traktowanie roślin matecznych światłem o zróżnicowanej barwie wpływało na morfologiczne zróżnicowanie sadzonek, jak również na zawartość w nich węglowodanów, co spowodowało wyraźne różnice $w$ ukorzenianiu się sadzonek. Dlugimi, licznymi korzeniami charakteryzowały się sadzonki uzyskane $z$ roślin wyrosłych przy świetle białym (kontrolnym) i czerwonym, natomiast najsłabszy system korzeniowy miały sadzonki uzyskane $z$ roślin uprawianych przy świetle zielonym.

Odmienny był wplyw stosowanych barw światła na tempo tworzenia się pierwszych korzeni na sadzonkach. Najszybciej ukorzeniały się sadzonki pochodzące z roślin traktowanych światlem zielonym, a następnie kolejno niebieskim, czerwonym i białym.

Stosowanie $\mathrm{w}$ trakcie ukorzeniania sadzonek zróżnicowanego pod względem barwy oświetlenia wywarło wpływ tylko na liczbę wytworzonych korzeni. Najliczniejsze korzenie wytworzyły sadzonki korzystające ze światła czerwonego, znacznie niższą liczbą korzeni charakteryzowały się sadzonki korzystające ze światła niebieskiego i zielonego. 